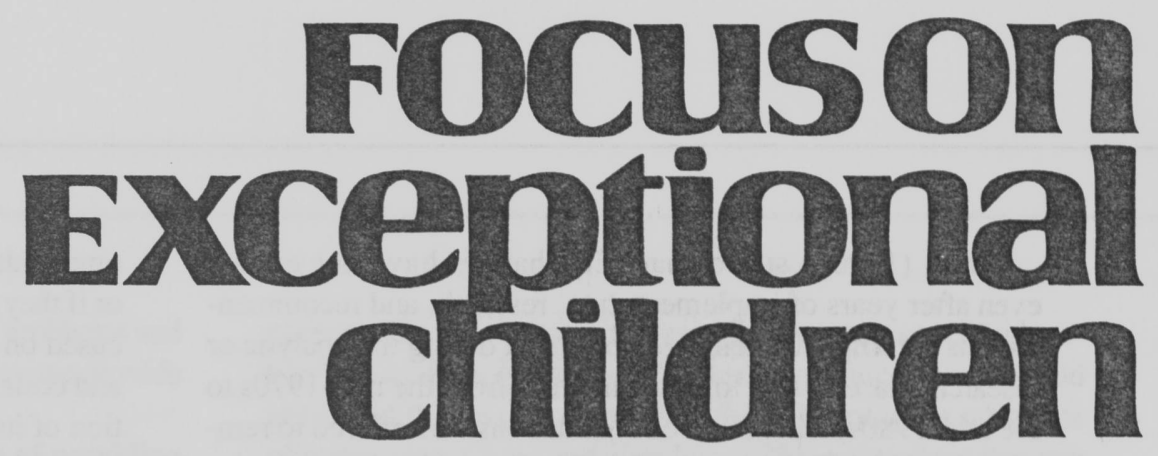

\title{
Individualized Education Program: Considering the Broad Context of Reform
}

\author{
Stephen W. Smith and Mary T. Brownell
}

The individualized education program (IEP) is the cornerstone of federal legislation that mandates the right to an educational opportunity for students with disabilities. The IEP is the vehicle that elaborates the right to an appropriate education and dictates the measures needed to achieve "specially designed instruction." It is a quasi-contractual agreement that presumably guides, orchestrates, and documents an educational career based on a student's unique academic and social needs.

Without question, the Education for All Handicapped Children Act of 1975 and the most recent reauthorization by Congress in 1990 known as the Individuals with Disabilities Education Act (IDEA) brought about much needed change in educational programs for students with disabilities. Conceptually, IDEA intended to reorient the goals of school personnel, parents, and students to obtain new outcomes. The IEP process arranged a way for professionals and parents to work together in achieving new educational priorities for students with disabilities based on equitable decision making and individual rights. As a result, the effectiveness of IDEA lies in the effectiveness of the IEP in the way it is "perceived, conceived, and carried out" (Kaye \& Aserlind, 1979, p. 138). Thus, the importance of the IEP in directing, documenting, and facilitating collaboration of a student's education cannot be minimized or ignored.

Since passage of IDEA, researchers have scrutinized the IEP document for procedural compliance and quality indicators. From these analyses researchers found the IEP process and document to be ineffective, incomplete, and faulty (e.g., Comptroller General of the United States, 1981; Pyecha et al., 1980; Smith, 1990b). Smith and Simpson (1989), for example, reported procedural faults in over half of the 214 IEPs of students with behavioral disorders, as well as low numbers of behavioral goals, few objectives met, and substantial deficits in the link between performance standards and annual goals.

In another study, Smith (1990a) found similar procedural and substantive deficits that undermine the validity, reliability, and accuracy of the IEP document. Research findings thus have highlighted the functioning of IEPs and questioned the value of continuing the current IEP process (Smith \& Simpson, 1989; Smith, 1990b). As it stands, IEPs have become what Neal and Kirp (1985) describe as "a narrow approach in which law and procedures become ends in themselves and substantive goals are lost in mechanical adherence to form" (p. 66).

Stephen Smith is an associate professor in the Department of Special Education at the University of Florida. Mary Brownell is an assistant professor in the Department of Special Education at the University of Florida. 
Smith (1990b) stated that IEP changes have not ensued even after years of implementation, research, and recommendations for improvement. He noted that during the analytic or research phase of IEP implementation (from the mid-1970s to the mid-1980s) a list of recommendations was offered to remedy identified IEP deficiencies. These recommendations included more inservice (Banbury, 1987; Nadler \& Shore, 1980), more informative IEP forms (Joseph, Lindgren, Creamer, \& Lane, 1983; Schipper \& Wilson, 1978), more preservice training (Schenck, 1981), better coordinated compliance enforcement (Dodaro \& Salvemini, 1985; McGarry \& Finan, 1982), and a modification in parent involvement (Gerardi, Grohe, Benedict, \& Coolidge, 1984). Despite these research efforts and recommendations, little has changed and we have no knowledge about whether IEPs actually affect student learning.

The next phase identified by Smith (1990b) was the technology-reaction or post-analytic phase. Curiously, the post-analytic phase did not consist of follow-up studies to see if rec-

\section{Focuson
Exceptional children}

ISSN 0015-511X

FOCUS ON EXCEPTIONAL CHILDREN (USPS 203-360) is published monthly except June, July, and August as a service to teachers, special educators, curriculum specialists, administrators, and those concerned with the special education of exceptional children. This publication is annotated and indexed by the ERIC Clearinghouse on Handicapped and Gifted Children for publication in the monthly Current Index to Journals in Education (CIJE) and the quarterly index, Exceptional Children Education Resources (ECER). The full text of Focus on Exceptional Children is also available in the electronic versions of the Education Index. It is also available in microfilm from Xerox University Microfilms, Ann Arbor, MI. Subscription rates: Individual, \$30 per year; institutions, $\$ 40$ per year. Copyright (C) 1995, Love Publishing Company. All rights reserved. Reproduction in whole or part without written permission is prohibited. Printed in the United States of America. Second class postage is paid at Denver, Colorado. POSTMASTER: Send address changes to:

Love Publishing Company

Executive and Editorial Office

1777 South Bellaire Street

Denver, Colorado 80222

Telephone (303) 757-2579

Edward L. Meyen

University of Kansas

Richard J. Whelan

University of Kansas Medical Center

Stanley F. Love

Publisher ommendations noted in the analytic phase were implemented or if they produced the desired effects. Instead, researchers focused on the effects of computer software to reduce the time and costs associated with the IEP without continued examination of its usefulness as a process and document. Simply automatizing the IEP to ensure a more expedient, less expensive process suggests a shift away from the original spirit and intent of IDEA (i.e., exemplary compliance) to minimal compliance. According to Smith, this shift is a "... failure of special education practice to conceptually embrace the concept of what we know about IEPs [analytic phase] versus what we do [post-analytic phase]. Thus, efforts now are undertaken to ensure minimal compliance, the very nature of which the [IDEA] was intended to preclude" (p. 11).

Smith's (1990b) review of the IEP literature indicates that professionals in special education have concentrated on medicating the symptoms of IEP inadequacies rather than analyzing the cause. He argued that attempts to improve the IEP process through more preservice and inservice training of professionals, improved parent participation and training, more effective professional collaboration, and computerization seem intuitive and reasonable measures, yet these recommendations have failed to create substantive change. We argue that prescribing remedies based on the readily observable problems associated with the IEP precludes meaningful reform. As a field, we have spent little time and effort understanding the design of IEPs and how they operate.

Change in the IEP process is unlikely because we have little understanding of why the IEP, within its larger context, continues to be ". . . ineffective as a tool for accountability, parental involvement, communication, and planning" (Bureau of Education for the Handicapped, 1979, p. 106). Smith (1990b) stated that “. . . perhaps we should acknowledge the IEP as nonviable and impractical and pursue other methods that show evidence of "specially designed instruction"' (p. 12).

We believe that, within its present context, the IEP is nonviable, yet the intent of the IEP (individualized problem solving to provide an appropriate education for students with disabilities) can flourish within a different context, one that allows the IEP process to continue as intended. We argue that, until professionals analyze the IEP within the school context and begin to recognize and evaluate its underlying assumptions, no real opportunity to bring about fundamental change will present itself. Rigorous debate about the IEP and its broader context can precipitate fundamental change. Debate will allow professionals to critically examine the factors in the current school context that prevent development of IEPs that meet the substantive intent of IDEA. Without it, we continu- 
ally will call for prescriptions to remedy current problems and little will happen to fundamentally change the way we provide educational opportunities for all students.

In this article we examine the current system of providing and documenting special education by analyzing the IEP through a number of its implicit and often unquestioned assumptions. Our goal is to look critically at the way we develop and implement IEPs so we can accommodate better the intent of "appropriate education" and assure systematic reform. Specifically, we want to explore the assumptions that (a) top-down policy making means successful implementation, (b) school organizations can create and sustain group decision making to accommodate individuality, and (c) teachers are rational and technical thinkers. We will conclude with possible directions for dialogue about IEP reform.

\section{TOP-DOWN POLICY MAKING MEANS SUCCESSFUL IMPLEMENTATION}

IEPs emerged from the legalization of special education and are influenced continuously by the organizational structure of schools and the professionals within them. The legalization of special education occurred as social policy initiatives in the 1960s, such as the civil rights movement and the War on Poverty, highlighted individual rights, and a host of court cases provided a mosaic of legal precedent (e.g., Pennsylvania Association for Retarded Citizens v. Commonwealth of Pennsylvania [1971], Mills v. D.C. Board of Education [1980]). It became clear in the 1970s that the right to an educational opportunity for all students with disabilities was not only reasonable but just. Under the guidance of attorneys, advocacy groups threatened litigation and lobbyists pressured states to legislate new educational initiatives for students with disabilities. Subsequently, momentum moved policy makers in Washington to finally enact federal legislation. Thus, the legalization of special education ensued and, along with the IEP component, was ". . . hailed by some as almost revolutionary in nature, changing the character of special education ..." (Morrissey \& Safer, 1977, p. 32).

Carved out of the legalistic model, the IEP carries a number of legal components that often frustrate and obviate the substantive intent of providing a quality educational program for students with disabilities. The assumption underlying the legal model is that we can construct, through force of law, an appropriate education for all students with disabilities. According to this model, there is ample evidence of the provision of appropriate education when all students in special education have legally sufficient IEPs on file that are agreed upon by parents. Though some will argue that entering special education and receiving services indicates compliance, others would argue that the true measure of the law's intent is the substance of instruction. Clune and Van Pelt (1985) pointed out that one weakness of legalization as a method of achieving an educational policy objective is the lack of educational substance. Instead, legalization captures the attention of an organization, making it a potentially useful means for garnering resources but not useful for suggesting educational solutions.

The law addresses accountability, a real and important issue for local education agencies (LEAs); however, it does not address quality issues and instructional appropriateness of the IEP for a specific student. Rather, the legalistic model relies heavily on due process and systematic review to ensure compliance while leaving little time for quality concerns. Some would argue that IEPs are the primary audit track for litigation and, therefore, their true character is a legal one, not one with an educational origin. Thus, a high degree of legal compliance becomes the central concern for LEAs with less focus on ensuring the provision of a quality education.

The focus on compliance rather than the educational significance of the IEP is what Clune and Van Pelt (1985) called "goal displacement" (p. 29) or what Neal and Kirp (1985) called the "the arid formality of legalism" (p. 82). Basically, it is easier for a bureaucracy such as a school district to initiate strenuous compliance procedures than to implement quality control initiatives (cf. Cuban, 1990; Elmore, 1980; Scott, 1987; Skrtic, 1991a; Weick, 1976, 1982).

\section{Where Policy Meets Practice}

The day-to-day demand of their job constrains the ability of school professionals to implement the intent of top-down initiatives such as the IEP. Weatherley and Lipsky's (1977) implementation study of state special education law in Massachusetts led them to conclude that "street-level bureaucrats"-in this case, teachers who are most responsible for the actual delivery of service-implement policy by first accommodating the demands placed upon them within the context of resource limitations. "They typically do this by routinizing procedures, modifying goals, rationing services, asserting priorities, and limiting or controlling clientele. . . . They develop practices that permit them in some ways to process the work they are required to do" (p. 172).

Further, Weatherley and Lipsky found that special education personnel respond to their environment by trying to secure control over it. They have to contrive their own strategies according to the demands of the workplace and its legal man- 
dates. Special education personnel attain control by becoming bureaucratically proficient rather than student-centered.

The behavior of teachers and other professionals as implementors of policy in schools is readily apparent in the development of IEPs. Many special and general education teachers work with students 6 to 7 hours a day with little time allotted for the type of planning and reflection envisioned by early IEP proponents. Lack of sufficient planning and reflection also constrain their opportunity to interact with parents and other professionals in any substantive way. As a consequence, administrators find ways to ease the burden of writing IEPs for teachers and other professionals by routinizing the procedures. For example, selecting goals and objectives from a standardized list or the available curriculum, having the special education teacher write the IEP before attending the meeting, and computerizing the IEP are all movements toward easing the procedural requirements. According to Lipsky's (1980) theory of street-level bureaucracy, the way that professionals in schools develop and implement IEPs is not just implementation of policy, it is the policy. In a real sense, IEP developers are de facto policy makers.

\section{Forward Mapping}

Elmore (1980) would not be surprised by Weatherley and Lipsky's 1977 study of street level bureaucrats. Elmore, however, would describe the behavior of teachers and other professionals who are implementors of IEP policy as the result of forward mapping. Forward mapping is a top-down process that begins with a clear statement of broad intent that continues through a series of more specific steps to define and articulate expectations of implementors at each level. "It begins with an objective, it elaborates an increasingly specific set of steps for achieving that objective, and it states an outcome against which success or failure can be measured" (p. 603).

IDEA started with congressional intent that was translated into rules and regulations, then formulated into a set of administrative responsibilities at varying federal, state, and local levels. At each point along the way, implementing units (e.g., federal offices, state agencies, school districts) would define an observable outcome that they deemed consistent with the original congressional intent for those whom the legislation would affect. Such is the case of the IEP. State education agencies and LEAs defined their mission of documenting an appropriate education through the IEP from federal intent and rules and regulations. They described, in their own rules and regulations, the expected outcomes for education professionals, parents, and especially students.
According to Elmore (1980), forward mapping is not without its weaknesses. An underlying assumption of forward mapping is that policy makers have direct or even some control of the organizational, political, and technological processes that affect implementation. This assumption, according to Elmore, is the "noble lie" of conventional public administration policy analysis. "By assuming that more explicit policy directives, greater attention to administrative responsibilities, and clearer statements of intended outcomes improve implementation, forward mapping reinforces the myth that implementation is controlled from the top" (p. 603).

Weatherley and Lipsky (1977), Lipsky (1980), and Elmore (1980) would agree that the success or failure of policy really is determined at the point where administrative intent encounters the private choice of street-level professionals (see also Mehan, Hertweck, \& Meihls, 1986). The legalization and implementation of special education becomes even more complex when legalization schemes, such as the IEP, are imposed on dynamic and complex organizations such as schools (Clune \& Van Pelt, 1985).

\section{DECISION MAKING BY SCHOOL ORGANIZA- TIONS TO ACCOMMODATE INDIVIDUALITY}

IDEA demands that the IEP be developed and implemented through the collaborative efforts of professionals, along with parents, to best meet the individual needs of students. For this to be achieved, Mintzberg (1979) and Skrtic (1991a) have suggested an adhocratic organization, wherein professionals work in an interdependent, collaborative fashion to invent new programs or, in the case of the IEP, new programs to meet the needs of individual students with disabilities. Schools, however, are professional bureaucracies that exist within the administrative structure of a machine bureaucracy. As such, they do little to foster collaboration between professionals and their students' parents (cf. Mintzberg, 1979; Scott, 1987; Skrtic, 1991a, 1991b; Weick, 1976).

In a machine bureaucracy, individuals perform simple work. Simple work "can be rationalized into a series of precise, routine tasks that can be fully prespecified and done by separate workers" (Skrtic 1991a, p. 162). The work performed on an automobile assembly line is an example of simple work. Each worker's duties are simple, routinized, and specified so the workers require little knowledge or skill to complete assigned tasks efficiently (Callahan, 1962; Mintzberg, 1979).

According to Skrtic, schools are managed like machine bureaucracies. This method of managing schools is the result of 
a rational and technical view of organizational leadership that attempts to make schools more efficient organizations (Callahan, 1962; Mintzberg, 1979; Skrtic, 1991a). The belief is that school failure is the result of inefficient organizations and that schools can become more efficient by prespecifying and standardizing the work of their employees to measure their productivity (Callahan, 1962). Managing schools like machine bureaucracies, however, is problematic because teaching becomes misconceptualized as simple work that can be rationalized and formalized (Skrtic, 1991a, 1991b), resulting in reduced professional discretion.

Teachers, however, perform complex work that is too ambiguous to be rationalized and prespecified (Rosenholtz, 1989). To accommodate this complex work, schools configure themselves as professional bureaucracies inside a machine bureaucracy configuration (see Skrtic, 1991a). The professional bureaucracy of a school establishes the division of labor through specialization of the professionals who work in it. For example, there are general and special education teachers of many types, reading and behavior specialists, guidance counselors, physical education and vocational education teachers. All of these teachers and specialists have acquired a standard set of skills through professional training that presumably allows them to meet the needs of the specific type of client they serve.

In a professional bureaucracy, teachers are performers, not problem solvers, because they most often work alone, with limited discretion, perfecting standard programs to serve their students (see Mintzberg, 1979). Their primary focus is on their students. They use their own specialized skills, not necessarily in concert with other teachers and school professionals who might have a different set of skills (Weick, 1982; Skrtic, 1991a). Generally, these professionals are aware of what everyone is doing during the school day, but they have only vague notions of each other's specific work or skills (Weick, 1976). School professionals, then, are in a loosely coupled form of interdependency wherein they are not highly dependent on each other (see also Cuban, 1990; Scott, 1987; Weick, 1976, 1982). Thus, the organization of schools and the organization of the professionals within it actually work against a collaborative process such as IEP development.

As a result of their ethnographic studies of special education practice in local school districts, Mehan et al. (1986) and Skrtic, Guba, and Knowlton (1985) have another view of the decision-making process. These researchers concluded that the decision making of professionals in a school district is a matter of economic, legal, and practical considerations rather than the intended individualized problem-solving approach that considers the unique needs of each student. Like Weatherley and Lipsky (1977), Mehan's and Skrtic's colleagues found that school professionals, faced with ever increasing demands on their time to develop IEPs, adopted informal methods of circumventing the rules and regulations by building informal procedures into the formal, established processes.

For example, Mehan et al. found that professionals in a small West Coast district handled the demand of special education referral, programming, and placement that culminated in an IEP by developing pre-placement planning, changing administrative reporting procedures, discouraging referrals during certain times of the year, and reducing the range of placement alternatives and availability of student programs. Mehan et al. also found that committee members at IEP meetings had little discussion about the range of placement alternatives nor did they consider the consequences of placement or programming. As a result, decision making between professionals and among IEP committee members became perfunctory, a matter of routine procedures that provided practical efficiency and a reduced sense of ambiguity.

Mehan and his colleagues argued that the district's available resources, school calendar, student demographics, and district finances influence a student's educational career more than their unique needs. This means that placing students in special education is really a matter of institutional routines and that "... student identities are constructed by the institutional practices of the school" (p. 159). Most often, developing an IEP is not a function of a student's characteristics, educational needs, or idiosyncratic conduct. Development of an IEP then ". . . is not so much a decision made as it is an enactment of routines" (p. 170).

\section{TEACHERS ARE RATIONAL AND TECHNICAL THINKERS}

We recognize that teachers are only a part of an IEP team, but they typically are responsible for a major portion of the design, instruction, and evaluation generated from IEP goals and objectives. For teachers, the IEP was to be the primary guide for designing and evaluating classroom instruction, yet its current design and implementation are at odds with the way teachers think. The assumption underlying the IEP is that teachers are rational and technical thinkers when teachers actually tend to approach instruction at a more intuitive level.

For almost two decades IEPs have been fashioned after the Tylerian approach to instructional planning and evaluation (Clark \& Peterson, 1986). Tyler, guided by a behavioral ap- 
proach to education, believed that effective instruction emanates from specified learning objectives. By identifying learning objectives, Tyler asserted that teachers could develop relevant instructional activities and criteria for evaluating instruction. This approach assumes that when educators determine objectives for student learning and evaluate their progress, the delivery of instruction is more effective and efficient.

Implicit in the design of IEPs is the notion that teachers use objectives and evaluation to drive the instruction they deliver. Such an assumption, however, is inherently flawed because teachers are not rational, linear thinkers (Clark \& Peterson, 1986; Gersten, 1990; Richardson, 1994). Teachers rarely use behavioral objectives to drive their instruction. Instead, teachers spend most of their planning time considering pupil activities that fit their conceptions of pupil needs, abilities, and interests, the subject matter to be taught, and the instructional strategies to be used in the lesson. Further, teachers direct little attention to evaluating their instruction or curriculum while planning (see Clark and Peterson's review). Researchers examining a teacher's use of Tyler's approach to planning and evaluating instruction found that experienced and novice teachers did not use the model in their planning (MorineDershimer \& Vallance, 1976; Neale, Pace, \& Case, 1983). Experienced teachers stated that, although they favored the Tylerian model, they did not employ it in their instruction because it was too time-consuming and unnecessary. These teachers thought that important components of the Tylerian model were implicitly rather than explicitly included in their formal planning (Neale et al., 1983).

Finally, a teacher's clinical view of classroom practice works against the use of IEPs in classrooms. Because teachers work in complex environments in relative isolation from their colleagues, they develop a "clinical" world view that is quite different from the orientation of university researchers. A clinician's world view is characterized by (a) an orientation to action, (b) faith in the efficacy of one's actions, (c) reliance on firsthand experience in decision making, (d) a crudely pragmatic approach to solving problems, and (e) distrust for generalizations drawn from theory (Friedson, 1970). Unlike university researchers, teachers reject using more scientific, distant sources of knowledge to resolve their problems or modify their instructional practices. Instead, teachers rely on their own and their peers' experiences (Huberman, 1983).

The IEP, however, emanates from the classical approach to scientific inquiry, an approach most often adhered to by researchers in special education (Skrtic, 1991a, 1991b). For almost two decades, parents and professionals developed IEPs based on students' strengths and weaknesses. The logic of identifying a student's strengths and weaknesses is to develop instructional goals and objectives to maintain strengths and remediate weaknesses. Further, effective instruction for individual students can be identified and implemented by evaluating progress toward these goals and objectives. The main difficulty with this logic, however, is that teachers do not employ it in thinking about instruction (McAninch, 1993).

Teachers tend to approach educational affairs intuitively rather than rationally. When asked to justify their professional decisions, teachers frequently use impulse and feeling rather than reflection and thought (Gersten, 1990; Jackson, 1968). Given the clinical nature of a teacher's thinking, it is little wonder that special educators find the IEP to be an instructionally irrelevant document (e.g., Dudley-Marling, 1985; Morgan \& Rhode, 1983). A teacher's view of the IEP, however, prompts a critical question: If teachers view the IEP as irrelevant to instruction, how can parents be assured that their child is receiving an individualized, appropriate education?

\section{POSSIBLE DIRECTIONS FOR DIALOGUE ABOUT IEP REFORM}

As we approach two decades of IEP implementation, overwhelming evidence shows that the substantive quality of the IEP and its influence on educational outcomes are questionable. Smith and Simpson (1989) and Smith (1990a, 1990b) concluded that little attention has been given to rectifying the problems of IEPs despite existing data that question the substantive contribution of documenting individualized programs for students with disabilities. Smith (1990b) argued for upgrading IEPs or modifying of the current educational system to facilitate better professional practice. We believe that the substantive intent of the IEP is achievable only through change in the mechanisms that prepare and allow educational professionals to truly individualize and evaluate educational programs.

We mentioned that professionals must begin to understand that creating an IEP occurs within an intricate environment that can inhibit collaborative decision making. IEPs exist and function according to many historical events and within organizational situations. Previously the emphasis was on conformity of policy through procedures and perfection of the IEP document rather than reflection on causes of IEP deficiencies. Recommendations to improve the IEP, including more preservice and inservice training, more informative IEP forms, better coordinated compliance enforcement, and a modification in parent involvement, are misdirected."We hesitate to pre- 
scribe or delineate what a new IEP could be. Rather, we present some ideas for changing the conditions that affect IEP development and implementation. In this way, we propose methods that will fulfill the intent and spirit of the IEP. The work of Elmore in describing forward and backward mapping, and of Mintzberg and Skrtic in conceptualizing adhocracies, may help us to conceptualize a new way of thinking about providing an appropriate education. Further, we discuss measures that teacher educators can take to promote the type of professional skills necessary for working effectively in an adhocratic structure.

\section{Backward Mapping}

Elmore (1980) revealed the inadequacies of forward mapping and also offered a unique method for achieving policy initiatives that emanate from the street level-that is, backward mapping. Backward mapping explicitly questions two assumptions of forward mapping.

1. Backward mapping rejects the assumption that policy makers do or even should exercise control over what happens in the implementation process.

2. It rejects the notion that explicit policy initiatives, delineated administrative responsibilities, and clearly defined outcomes will increase the successful implementation of policy.

Backward mapping logically is the opposite of forward mapping. It begins not at the top but, rather, where administrative action meets street-level decision making. Forward mapping begins with a statement of intent, but backward mapping begins with a statement of the behaviors at the street level that generate the need for policy. From these behaviors, organizational operations and a set of effects or outcomes become objectives. The objectives then are backed up through the system of implementing agencies with two questions asked at each level: What is the ability of this unit to affect the behavior that is the target of the policy? "What resources does this unit require to have the desired effect?" (Elmore, 1980, p. 604). At the final stage, the policy maker or analyst describes a policy that directs organizational resources at the unit most likely to have the greatest effect.

Backward mapping assumes that the closer a professional is to the source of the problem, the greater is his or her ability to influence or solve it. Maximizing discretion where the problem is most immediate accomplishes successful implementation of policy. Teachers, parents, and other professionals would articulate barriers to creating, implementing, and evaluating individualized progiams. Resources then could be targeted to reduce or eliminate those barriers. Backward mapping maximizes discretion in making programming decisions based on a child-centered approach or needs approach by increasing the knowledge and problem-solving ability of lowerlevel or street-level professionals. Backward mapping focuses attention on reciprocity and discretion. "It emphasizes, in other words, that it is not the policy or the policy maker that solves the problem, but someone with immediate proximity" (Elmore, 1980, p. 612).

For professionals involved in any decision making about their students, (e.g., the IEP), it is easy to see how backward mapping can change our thinking about educational concerns. It is essential to ask teachers and other professionals how they go about their work and the nature of their planning for students and their instruction. Through collaboration, policy makers can "use the structure and process of organizations to elaborate, specify, and define policies" (Elmore, 1980, p. $606)$. By identifying implementation needs, policy makers can provide resources that will enhance professionals' abilities to use their skill and professional judgment in implementing the IEP process.

\section{Adhocratic Forms}

Mintzberg and Skrtic, like Elmore, offer the adhocracy as a new way of configuring professionals. They believe that an adhocratic structure would increase professional discretion and mutual adjustment to solving problems. We will not offer a complete treatise of the adhocratic form here; rather, we want to introduce it as a new way of thinking about our educational practices, especially our practice of individualizing educational programs.

The adhocracy is a highly decentralized, structural configuration. The adhocracy contains little formalization of behavior, and professionals and managers work in multidisciplinary teams around specific projects of innovation. It is a dynamic, self-renewing form devoid of all the trappings of the bureaucratic structure such as division of labor, formalized worker behavior, rule following and instrumentality, with emphasis on planning, coordination, and control mechanisms. The organizational structure is horizontal as opposed to hierarchical, and professionals are given power to use their discretion in making decisions (Mintzberg, 1979). The avant-garde filmmaker, think-tank consultant firms, and innovative advertising agencies are examples of organizations sometimes configured around the ad hoc project form. Mintzberg stated that the adhocracy is truly tomorrow's structure. It is a structure 
for a population growing ever better educated and more specialized. ... It is a structure for environments becoming more complex and demanding of innovation. ... It is the only structure now available to those who believe organizations must become at the same time more democratic yet less bureaucratic. (p. 459-460)

When IDEA became law, an adhocratic organization was necessary to meet the substantive intent of the IEP (Skrtic, 1991a). The individualized nature of the IEP requires innovation, not standardization. Implicit in the development of an IEP was that professionals and parents would collaborate to create new programs because each student is unique and requires individualized problem solving. Existing programs, rules, and policies are irrelevant because each program would have to be invented and reinvented through mutual adjustment of the collaborators. New multidisciplinary knowledge would evolve through the cumulative knowledge and skills of the numerous professionals. The adhocracy is the only organizational configuration capable of creating new knowledge through the collaborative efforts of multidisciplinary team members.

If schools were to become configured as adhocracies, ad hoc project teams of various specialized professionals and parents would come together to solve problems. The efforts of the project team must be innovative; thus, their work would preclude reliance on standardized programs and procedures. Direct supervision of the project group becomes unnecessary because their work is complex, they do not rely on standard programs, and only those in the ad hoc groups have the requisite knowledge to do and understand the project's work. Thus, creating true individualized education programs for students based on their unique needs can occur only through ad hoc project teams of various individuals who coordinate their work through mutual adjustment.

One example of this could be Personal Futures Planning (Mount \& Zwernik, 1988). Personal Futures Planning (PFP) is an innovative way to develop individualized programs because it

is an ongoing problem-solving process. It comes about through a small group of people who agree to meet for mutual support, brainstorming, and strategizing. This circle of support or person-centered team makes commitments and takes action to ensure that changes will be accomplished for the focus person. (p. 1)

Also, when engaging in PFP, individualized goals are developed by those who know the student the best, and not based solely on what the schools have to offer in curriculum (Smith, Slattery, \& Knopp, 1993).

\section{Teachers in the Adhocratic Form}

The adhocratic organization also is necessary for moving teachers from intuitive, subjective ways of understanding classroom phenomena to more constructive ways. Teachers who are constructive knowers integrate their intuitive knowledge about the classroom with knowledge they acquire from other sources. They are capable of "weaving together the strands of rational and emotive thought and of integrating objective and subjective knowing" (Belenky, Clinchy, Goldberger, \& Tarule, 1986, p. 14). Although teachers who are constructive knowers are not rational, technical thinkers, they are able to see linkages between their personal experiences and research. They "are challenged by problems of inquiry [that each student with a disability presents] and can cut across disciplines and perspectives to approach problems" (McAninch, 1993, p. 31).

Constructivist teachers "can inquire about and reflect on the alternatives before them and place at the center [of their] decisions the idea of caring" and doing their best for individual students (McAninch, 1993, p. 31). This type of thinking is essential to a collaborative, decision-making process that focuses on individual students, the basic premise of the IEP. The adhocracy requires and sustains this type of thinking because multidisciplinary teams work together to solve common problems through mutual adjustment and, as a consequence, team members expand their individual knowledge bases and perspectives through the shared expertise and experience of the group (Mintzberg, 1979).

Teacher education programs also have potential to develop professionals who are constructive thinkers, a necessity for individualized problem solving, through new instructional methodologies and cross-department collaboration. Case methodology and practical inquiry are instructional techniques that teacher educators can use to help promote constructive thinking in their students (McAninch, 1993; Richardson, 1994). Case methodology engages preservice students in critical analysis of actual classroom situations. In analyzing cases, preservice students apply what they know about theory and research to the classroom scenario. In addition, students take different theoretical perspectives in analyzing a single case. Case analysis promotes constructive thinking because preservice students must integrate subjective and rational thinking and engage in divergent thinking as they consider a variety of theoretical explanations for classroom phenomena. Along 
with their professional specialization skills, ad hoc project team members would need constructive thinking skills when faced with the task of building educational programs.

Practical inquiry is another vehicle for promoting constructive thinking in preservice students. Practical inquiry is an attempt to systematically collect data that offer insight into professional practice (Clift, Veal, Johnson, \& Holland, 1990). Practical inquiry helps preservice students understand school and classroom contexts and practices as well as the students they teach. In practical inquiry, preservice students are encouraged to use theory and research to find new ways of looking at the operative school context as well as student progress and possible changes in practice. Preservice students do not engage in practical inquiry for "purposes of developing general laws related to educational practice [or to find] the answer to a problem" (Richardson, 1994). Rather, preservice students would examine school and classroom problems through multiple lenses.

Case methodology and practical inquiry, however, should not be used by departments working in isolation. Instead, these techniques should provide a focal point for preservice students and faculty collaborating across departments. Collaboration across departments will enhance the multiple perspective taking that is necessary in a successful adhocratic organization. Further, engaging students in collaboration in their preservice programs will enhance their skills for surviving and thriving in an adhocratic form.

\section{CONCLUSION}

In summary, we suggest dramatic changes in policy implementation, teacher education, and school organizations. These changes will create a context in which to develop and implement IEPs with the original spirit and intent of the law. Education professionals and policy makers who consider reinventing education, however, will confront many barriers. First, because of the legalization of special education, accountability demands from federal and state departments of education, legislators, and community members make it difficult for educators to employ professional discretion in decision making. Second, most general and special education teachers and related service professionals receive their professional credentials through separate training programs. Consequently, they may not have had sufficient opportunity to develop collaborative skills along with those outside their profession. Third, the existing continuum of services precludes teachers, parents, and other professionals from working together to invent new programs based on the unique needs of students. When standard programs exist, professionals operate to refine those programs rather than invent new ones (Mintzberg, 1979; Skrtic, 1991a). Finally, ad hoc project teams require a surfeit of time to create new programs that emanate from discursive dialogue. Time for reflective thinking and planning are necessary for participation in ad hoc project groups-something not readily available in the current structure of schools.

We agree with Schlechty (1990) and Clark and Meloy (1990), who insist on radical restructuring of our public school system. Schlechty says that “... nothing short of fundamental restructuring of schools will suffice if the continuing vitality of public education is to be assured. Repair of existing structure is not enough" (p. 233). Radical change will involve critically analyzing current practices in special education that inhibit the provision of individualized appropriate education. Such an analysis will require arduous examination of many beliefs about the viability of the way we currently practice special education. Radical reform, however, cannot occur without rigorous debate about the problems underlying identified deficiencies in the IEP process and document.

This article represents our intent to start a discourse about change, and specifically how we can go about providing an appropriate education through IEPs for all students with disabilities. Without reflection and discursive dialogue, providing and documenting individualized programming via the IEP will not evolve.

\section{REFERENCES}

Banbury, M. (1987). The IEP revisited: A look at the concept and reality. In A. Rotatori, M. Banbury, \& R. A. Fox (Eds.), Issues in special education (pp. 42-50). New York: Mayfield.

Belenky, M. F., Clinchy, N. R., Goldberger, N. R., \& Tarule, J. M. (1986). Women's ways of knowing: The development of self, voice, and mind. New York: Basic Books.

Bureau of Education for the Handicapped. (1979). Progress toward a free, appropriate public education. A report to Congress on the implementation of Public Law 94-142: The Education for All Handicapped Children Act. Washington, DC: Author. (ERIC Document Reproduction Service No. ED 175 196)

Callahan, R. E. (1962). Education and the cult of efficiency. Chicago: University of Chicago Press.

Clark, D. L, \& Meloy, J. M. (1990). Recanting bureaucracy: A democratic structure for leadership in schools. In A. Lieberman (Ed.), Schools as collaborative cultures: Creating the future now (pp. 3-23). New York: Falmer Press.

Clark, C. M., \& Peterson, P. L. (1986). Teachers' thought processes. 
In M. C. Wittrock (Ed.), Handbook of research on teaching (3rd ed., pp. 225-296). New York: Macmillan.

Clift, R., Veal, M. L., Johnson, M., \& Holland, P. (1990). The restructuring of teacher education through collaborative action research. Journal of Teacher Education, 41(2), 104-118.

Clune, W. H., \& Van Pelt, M. H. (1985). A political method of evaluating the Education for All Handicapped Children Act of 1975 and the several gaps of gap analysis. Law and Contemporary Problems, 48, 7-62.

Comptroller General of the United States. (1981). Unanswered questions on educating handicapped children in local public schools. Washington, DC: Author. (ERIC Document Reproduction Service No. 175 196)

Cuban, L. (1990). Reforming again, again, and again. Educational Researcher, 19, 3-13.

Dodaro, G. L., \& Salvemini, A. N. (1985). Implementation of P.L. 94-142 as it relates to handicapped delinquents in the District of Columbia. Washington DC: U.S. General Accounting Office.

Dudley-Marling, C. (1985). Perceptions of the usefulness of the IEP by teachers of learning disabled and emotionally disturbed children. Psychology in the Schools, 22, 65-67.

Elmore, R. F. (1980). Backward mapping: Implementation research and policy decisions. Political Science Quarterly, 94, 601-616.

Friedson, E. (1970). Profession of medicine. Chicago: University of Chicago Press.

Gerardi, R. J., Grohe, B., Benedict, G. C., \& Coolidge, P. G. (1984). IEP-More paperwork and wasted time. Contemporary Education, 56(1), 39-42.

Gersten, R. (1990). Enemies real and imagined: Implications of "teachers' thinking about instruction" for collaboration between special and general education. Remedial \& Special Education, 11(6), 50-53.

Huberman, M. (1983). Recipes for busy kitchens. Knowledge: Creation, diffusion, utilization, 4, 478-510.

Jackson, P. W. (1968). Life in classrooms. New York: Holt, Rinehart \& Winston.

Joseph, J., Lindgren, J., Creamer, S., \& Lane, K. (1983). Evaluating special education: A study to pilot techniques using existing data in Skokie School District 68. Skokie, Il: Skokie School District 68. (ERIC Document Reproduction Service No. ED 227 176)

Kaye, N. L., \& Aserlind, R. (1979). The IEP: The ultimate process. Journal of Special Education, 13, 137-143.

Lipsky, M. (1980). Street-level bureaucracy: Dilemmas of the individual in public services. New York: Russell Sage Foundation.

McAninch, A. R. (1993). Teacher thinking and the case method: Theory and future directions. New York: Teachers College Press.

McGarry, J., \& Finan, P. L. (1982). Implementing Massachusetts' special education law: A statewide assessment. Final report. Boston: Massachusetts State Department of Education. (ERIC Document Reproduction Service No. ED 226 542)
Mehan, H., Hertweck, A., \& Meihls, J. L. (1986). Handicapping the handicapped. Stanford: Stanford University Press.

Mintzberg, H. (1979). The structuring of organizations. Englewood Cliffs, NJ: Prentice Hall.

Morgan, D. P., \& Rhode, G. (1983). Teacher's attitudes toward IEPs: A two year follow-up. Exceptional Children, 50, 64-67.

Morine-Dershimer, G., \& Vallance, E. (1976). Teacher planning (Beginning teacher evaluation study, special report C). San Francisco: Par West Laboratory.

Morrissey, P. A., \& Safer, N. (1977). Implications for special education: The individualized education program. Viewpoints, 53, 31-38.

Mount, B., \& Zwernik, K. (1988). It's never too early, its never too late: A booklet about personal futures planning (Publication No. 421-88-109). St. Paul: Metropolitan Council.

Nadler, B., \& Shore, K. (1980). Individualized education programs: A look at realities. Education Unlimited, 2, 30-34.

Neal, D., \& Kirp, D. L. (1985). The allure of legalization reconsidered: The case of special education. Law \& Contemporary Problems, 48, 63-87.

Neale, D. C., Pace, A. J., \& Case, A. B. (1983, April). The influence of training, experience, and organizational environment on teachers' use of the systematic planning model. Paper presented at annual meeting of American Educational Research Association, Montreal.

Pyecha, J. N., Cox, J. L., Dewitt, D., Drummond, D., Jaffe, J., Kalt, M., Lane, C., \& Pelosi, J. (1980). A national survey of individualized education programs (IEPs) for handicapped children (5 vols.). Durham, NC: Research Triangle Institute. (ERIC Document Reproduction Service Nos. ED 199 970-974)

Richardson, V. (1994). Conducting research of practice. Educational Researcher, 23(5), 5-10.

Rosenholtz, S. J. (1989). Teachers' workplace: The social organization of schools. White Plains, NY: Longman.

Schenck, S. J. (1981). An analysis of IEPs for LD youngsters. Journal of Learning Disabilities, 14, 221-223.

Schipper, W., \& Wilson, W. (1978). Implementation of individualized educational programming: A problem or an opportunity? Washington, DC: National Association of State Directors of Special Education (NASDSE). (ERIC Document Reproduction Service No. ED 155881 )

Schlechty, P. C. (1990). Schools for the twenty-first century: The conditions for invention. In A. Liegerman (Ed), Schools as collaborative cultures: Creating the future now (pp. 233-355). New York: Falmer Press.

Scott, W. R. (1987). Organizations: rational, natural and open systems. Englewood Cliffs, NJ: Prentice Hall.

Skrtic, T. M. (1991a). Behind special education: A critical analysis of professional culture and school organization. Denver: Love Publishing.

Skrtic, T. M. (1991b). The special education paradox: Equity as the way to excellence. Harvard Educational Review, 61(2), 148-206. 


\title{
NEW FOR 1996
}

\section{Teaching Adolescents with Learning Disabilities: Strategies and Methods-Second Edition}

\author{
Donald Deshler, University of Kansas \\ Edwin Ellis, University of Alabama \\ Keith Lenz, University of Kansas
}

\section{At last-the new second edition of this classic learning strategies instruction book is now available.}

This text comprises current successful learning strategies and how to teach them effectively to adolescents. The featured strategies emphasize thinking processes, self-regulation, and problem solving through an instructional approach. Based on the approach that instruction involves interactions between the individual and the environment, this book encourages teachers to understand the environment and how their students perceive it.

The text presents a wide range of general strategies that can be applied to all content areas. The goal is to identify strategies that are effective so the student learns and generalizes them. You'll also find new information on memory, notetaking, test-taking, social skills, transition, and collaborative skills.

\section{Special Features}

- Solid empirical base

- Contains advanced organizers at the start of each chapter

- Complete revision of all chapters

- Covers academic, social, and transition concerns

- Written by expert authors who understand the needs of adolescents

- Provides step-by-step procedures for each stage of strategy acquisition and generalization

- Incorporates proven techniques that work with adolescents

\section{Contents}

1. Learning Disabilities in Adolescents: A Perspective

2. Perspectives on Instruction in Learning Strategies

3. Reading Strategy Instruction

4. Writing Strategy Instruction

5. Memory and Test-Taking Strategies

6. Notetaking Strategy Instruction
7. Perspectives on Mathematics Instruction

8. Social Skills Strategy Instruction

9. Strategic Instruction in the Content Areas

10. Strategies for Transition to Postsecondary Educational Settings

11. Strategies for Transition to Employment Settings

12. Collaborative Teaming in the Secondary School 
Skrtic, T. M., Guba, E. G., \& Knowlton, H. E. (1985). Interorganizational special education programming in rural areas: Technical report on the multisite naturalistic field study (Contract No. 400-81-0017). Lawrence: University of Kansas, Department of Special Education.

Smith, S. W. (1990a). Comparison of individualized education programs (IEPs) of students with behavioral disorders and learning disabilities. Journal of Special Education, 24, 85-100.

Smith, S. W. (1990b). Individualized education programs (IEPs) in special education-From intent to acquiescence. Exceptional Children, 57, 6-14.

Smith, S. W., \& Simpson, R. L. (1989). An analysis of individualized education programs (IEPs) for students with behavioral disorders. Behavioral Disorders, 14(2), 107-116.
Smith, S. W., Slattery, W. J., \& Knopp, T. Y. (1993). Beyond the mandate: Developing individualized education programs that work for students with autism. Focus on Autistic Behavior, 8(3), $1-14$.

Weatherley, R., \& Lipsky, M. (1977). Street-level bureaucrats and institutional innovation: Implementing special-education reform. Harvard Educational Review, 47(2), 171-197.

Weick, K. E. (1976). Educational organizations as loosely coupled systems. Administrative Science Quarterly, 21, 1-19.

Weick, K. E. (1982). Administering education in loosely coupled schools. Phi Delta Kappan, 63, 673-676.

\section{Professional Update}

October 26-28, 1995

Council for Learning Disabilities

Fairmount Hotel

Chicago, Illinois

Contact: CLD, Kristen McBride, (913) 492-8755
November 30-December 2, 1995

Association for Persons with Severe Handicaps

Hilton Hotel and Towers

San Francisco, California

Contact: TASH, Denise Marshall, (410) 282-TASH

PERMISSIONS AND COPYRIGHT • All rights are reserved. No part of this publication may be reproduced, photocopied, faxed, stored in a retrieval system, or transmitted, in any form or by any means, electronic, mechanical, recording or otherwise, without the prior written permission of the publisher. - Back issues are available for sale. Reproduction requires permission and payment of fees. It is illegal and a violation of federal copyright law to reproduce this publication without permission. Direct all inquiries to the permissions editor. 